\title{
FAKTOR-FAKTOR PENYEBAB KERUSAKAN FISIK REKAM MEDIS RAWAT JALAN DI PUSKESMAS PASEH
}

\author{
Rahma Suci Hadiyanti ${ }^{1 *}$, Muhammad Ihsan Hafizhan ${ }^{2}$, Sali Setiatin ${ }^{3}$ \\ Politeknik Piksi Ganesha Bandung, Indonesia ${ }^{1,2,3}$ \\ piksi.rahma.18303083@gmail.com ${ }^{1 *}$, mihafizhan@piksi.ac.id ${ }^{2}$, salisetiatin@gmail.com³
}

Received: 17-09-2021

Revised : 20-10-2021

Accepted: $25-10-2021$

\begin{abstract}
Abstrak
Latar Belakang : Dokumen Rekam Medis merupakan alat untuk merekam mencatat terjadinya transaksi pelayanan. Sehingga berkas rekam medis dapat memberikan informasi yang akurat dan berkesinambungan, mutu pelayanan dapat ditingkatkan bila didukung oleh keamanan dan kerahasiaan berkas rekam medis pasien di ruang penyimpanan, dokumen rekam medis harus dikelola dengan baik karena mempunyai nilai manfaat yang besar bagi puskesmas. Pengelolaan dokumen rekam medis memerlukan penyimpanan, pengamanan dan pemeliharaan supaya tidak rusak.
\end{abstract}

Tujuan : Penelitian ini bertujuan untuk mengetahui apa saja faktor-faktor benyebab kerusakan fisik rekam medis rawat jalan di Puskesmas Paseh.

Metode : Penelitian ini menggunakan metode kualitatif dengan pendekatan deskriptif dan pengumpulan data dengan praktik kerja lapangan atau observasi, studi pustaka dan wawancara yang mendalam kepada perekam medis dengan menggunakan analisis unsur manajemen 5M (Man, machine, method, material, dan Money).

Hasil : 100 rekam medis yang mengalami kerusakan dengan kualitas map putih berbahan tipis sehingga formulir didalamnya bisa ikut rusak atau robek. Di Puskesmas Paseh terdapat 1 dari 3 perekam medis yang memiliki latar belakang pendidikan bukan D3 rekam medis, tidak adanya SOP terkait pemeliharaan rekam medis, kurangnya rak penyimpanan serta kapasitas ruangan yang kurang luas, dan bahan data pasien masih ada yang menggunakan map dokumen yang kurang tebal.

Kesimpulan : Pemeliharaan rekam medis di Puskesmas Paseh tergolong cukup namun ada beberapa yang perlu di lakukan seperti meningkatkan pelatihan perekam medis terkait pemeliharaan rekam medis, menambah rak penyimpanan, memperluas ruangan, serta membuat standar prosedur operasional (SPO) terkait perlindungan dan pemeliharanan dokumen rekam medis.

Kata kunci: rekam medis; kerusakan; rawat jalan; puskesmas. 
Background: Medical Record Document is a tool to record the occurrence of service transactions. So that medical records files can provide accurate and continuous information, the quality of service can be improved when supported by the security and confidentiality of patient medical records files in storage rooms,.. Medical records documents must be managed properly because it has great benefit value for health centers. Management of medical record documents requires storage, security and maintenance so as not to be damaged.

Objective: This study aims to determine what are the factors that cause physical damage to outpatient medical records at the Paseh Health Center.

Methods: This research uses qualitative methods with descriptive approaches and data collection with fieldwork or observation practices, literature studies and in-depth interviews to medical recorders using analysis of $5 \mathrm{M}$ management elements (Man, machine, method, material, and Money).

Result: 100 damaged medical records with white folder quality made of thin so that the forms inside can be damaged or torn. At Push Health Center there are 1 out of 3 medical recorders who have an educational background, not D3 medical records, there is no SOP related to medical record maintenance, lack of storage racks and less spacious room capacity, and patient data materials still used document folders that are not thick

Conclusion: Maintenance of medical records at the Paseh Health Center is sufficient but there are several things that need to be done such as increasing medical record training related to medical record maintenance, adding storage shelves, expanding the room, and making standard operating procedures (SPO) related to the protection and maintenance of medical record documents.

Keywords: medical record; damage; outpatient; public health center.

*Correspondent Author : Rahma Suci Hadiyanti Email : piksi.rahma.18303083@gmail.com

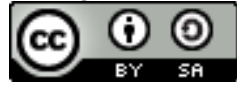

\section{PENDAHULUAN}

Sesuai dengan PERMENKES No. 75 Tahun 2014 Pusat Kesehatan Masyarakat atau Puskesmas adalah fasilitas pelayanan kesehatan yang menyelenggarakan upaya kesehatan masyarakat dan upaya kesehatan perseorangan tingkat pertama, dengan lebih mengutamakan upaya promotif dan preventif, untuk mencapai derajat kesehatan masyarakat yang setinggi-tingginya di wilayah kerjanya (Purnamasari et al., 2017). Puskesmas merupakan unit pelaksanaan teknis dinas kesehatan kabupaten/kota yang bertanggungjawab menyelenggarakan pembangunan kesehatan disuatu wilayah kerja. 
Rekam medis merupakan salah satu faktor penting penunjang pelayanan puskesmas (Suryanto, 2020).

Menurut Permenkes No. 269/Menkes/Per/III/2008 tentang Rekam Medis adalah berkas yang berisikan catatan dan dokumen tentang identitas pasien, pemeriksaan, pengobatan, tindakan dan pengobatan lain yang telah diberikan kepada pasien. Rekam Medis juga dapat diartikan sebagai keterangan baik yang tertulis maupun yang terekam tentang identitas, anamnese, penentuan fisik laboratorium, diagnosis segala pelayanan dan tindakan medis yang diberikan kepada pasien, dan pengobatan baik rawat jalan maupun rawat inap (Permenkes, 2008).

Dokumen Rekam Medis merupakan alat untuk merekam mencatat terjadinya transaksi pelayanan. Sehingga berkas rekam medis dapat memberikan informasi yang akurat dan berkesinambungan, mutu pelayanan dapat ditingkatkan bila didukung oleh keamanan dan kerahasiaan berkas rekam medis pasien di ruang penyimpanan berkas rekam medis itu sendiri (Sebayang, 2018).

PMK No. 312 Tahun 2020 tentang Standar Profesi Perekam Medis dan Informasi Kesehatan menegaskan bahwa profesi Perekam Medis dan Informasi Kesehatan (PMIK) di setiap fasilitas pelayanan kesehatan dituntut untuk memberikan pelayanan informasi kesehatan yang profesional dan berorientasi pada kebutuhan informasi kesehatan bagi pemberi layanan kesehatan (Garmelia et al., 2021).

Adapun pengelolaan rekam medis itu sendiri yaitu merupakan salah satu bentuk dari pelayanan penunjang medis. Sistem pengelolaan rekam medis sendiri di mulai dari tempat penerimaan pasien (menyiapkan atau membuatkan berkas rekam medis), dilanjut dengan assembling, coding, indexing dan filing. Pada bagian filing penyimpanan dan pengembalian kembali rekam medis dilakukan, penyimpanan berkas rekam medis bertujuan untuk mempermudah dan mempercepat pengambilan dan pengembalian berkas rekam medis yang tersimpan, juga melindungi berkas rekam dari berbagai faktor diantaranya yaitu bahaya pencurian, faktor intrinsik dan faktor ekstrinsik (Sebayang, 2018).

Faktor instrinsik adalah penyebab kerusakan yang berasal dari dokumen itu sendiri, misalnya kualitas kertas, pengaruh tinta, dan pengaruh perekat. Sedangkan faktor ekstrinsik sendiri adalah penyebab kerusakan yang berasal dari luar rekam medis, misalnya faktor lingkungan fisik, faktor biologis berupa serangga atau hewan misalnya kutu, kecoa, rayap, tikus dan jamur, dan faktor kimiawi (Yuliani, 2016).

Menurut Permenkes No. 55 Tahun 2013 tentang Penyelenggaraan Pekerjaan Perekam Medis Pasal 1 yaitu Manajemen Pelayanan Rekam Medis dan Informasi Kesehatan adalah kegiatan menjaga memelihara dan melayani rekam medis baik secara manual maupun elektronik sampai menyajikan informasi kesehatan di rumah sakit, praktek dokter klinik, asuransi kesehatan, fasilitas pelayanan kesehatan dan lainnya yang menyelenggarakan pelayanan kesehatan dan menjaga rekaman (Sandika, 2019).

Puskesmas Paseh diresmikan pada tahun 2010 dengan menggunakan sistem penyimpanan sentralisasi, sistem penomoran menggunakan serial numbering system, dan menggunakan sistem penjajaran nomor langsung (Straight Numerical Filing). Berdasarkan hasil observasi dan wawancara kepada salah satu perekam medis, serta praktek kerja lapangan di Puskesmas Paseh menyatakan bahwa rekam medis di Puskesmas Paseh terdapat 2 (dua) rekam medis dengan map yang berbeda, yang pertama rekam medis dengan menggunakan map hijau yang berbahan tebal dan yang kedua dengan map putih yang berbahan tipis. Rekam medis dengan map putih yang berbahan tipis inilah yang membuat dokumen mudah rusak atau robek, dikarenakan belum semua dokumen diganti dengan map hijau yang kualitasnya lebih tebal, kurangnya rak penyimpanan dan ruangan yang kurang memadai serta baru sebagian dokumen yang di retensi. Keamanan merupakan keadaan bebas dari bahaya dan merupakan faktor yang sangat penting dalam pengelolaan rekam medis ( Kholifah et al., 2020). 
Berdasarkan hasil penelitian di Puskesmas Paseh bahwa rekam medis yang rusak dikarenakan sampul map tipis yang menyebabkan dokumen mudah robek sehingga menyebabkan formulir didalam nya terlipat dan jika dibiarkan semakin lama maka akan robek. Penyebab rusaknya rekam medis juga disebabkan oleh kurangnya rak penyimpanan serta keadaan ruangan yang tidak memadai. Selain itu penyebab lainnya juga dikarenakan kurangnya pelatihan rekam medis terkait bagian filing, serta tidak adanya SOP terkait perlindungan dan pemeliharaan dokumen rekam medis. Standar Prosedur Operasional (SPO) adalah pedoman atau acuan untuk melaksanakan tugas dan pekerjaan sesuai dengan fungsi dari pekerjaan tersebut, dengan adanya SPO semua kegiatan di suatu instansi dapat terancang dengan baik dan berjalan sesuai kemauan instansi. SPO dapat didefinisikan sebagai berkas yang menjabarkan aktivitas operasional yang dilakukan sehari-hari dengan tujuan agar pekerjaan tersebut dilakukan dengan benar, tepat, dan konsisten untuk menghasilkan produk agar sesuai dengan standar yang telah ditetapkan sebelumnya (Gabriele, 2018).

Sesuai dengan penelitian (Arif, 2018) menyatakan bahwa pemeliharaan rekam medis merupakan kegiatan yang bertujuan untuk menjaga keselamatan dokumen dengan cara menyimpan, merawat, melindungi dokumen dari faktor-faktor yang dapat merusak dan memusnahkan dokumen rekam medis. Faktor yang mengakibatkan kurang optimalnya pemeliharaan rekam medis adalah faktor sumber daya manusia (SDM) serta faktor sarana dan prasarana. Menurut (Sandika, 2019) bahwa faktor lain yang menyebabkan kurang optimalnya pelaksanaan pemeliharaan rekam medis adalah belum adanya standar prosedur operasional (SPO) tentang pemeliharaan rekam medis itu sendiri (Ayuningrum et al., 2020). Penelitian sebelumnya kondisi ruangan dalam keadaan berantakan dikarenakan belum dilaksanakan retensi, akan tetapi setelah dilakukan penelitian saat ini kondisi ruangan dalam keadaan sudah rapi dikarenakan sedang dilaksanakan retensi, serta penataan dokumen yang terlalu padat sekarang sudah mulai renggang dan sebagian dokumen yang belum dilakukan pembaruan cover saat ini sudah banyak dokumen yang dilakukan pembaruan cover. Namun untuk SOP sendiri sampai saat ini masih belum ada begitu juga dengan rak penyimpan dan ruangan masih sama.

Tujuan penelitian ini yaitu untuk mengetahui faktor-faktor penyebab terjadinya kerusakan fisik pada rekam medis rawat jalan di Puskesmas Paseh. Maka dari itu berdasarkan permasalahan diatas penulis mengambil judul apa saja faktor-faktor penyebab dari kerusakan fisik rekam medis dan bagaimana upaya yang akan dilakukan dalam perbaikan dan pemeliharaan dokumen agar terhindar dari kerusakan.

\section{METODE PENELITIAN}

Adapun jenis penelitian yang digunakan yaitu menggunakan analisis kualitatif dengan pendekatan deskriptif. Jenis analisis ini digunakan untuk mencari apa saja faktorfaktor penyebab dari rusaknya rekam medis dan bagaimana upaya perbaikan dan pemeliharaan yang akan dilakukan agar terhindar dari kerusakan dengan menggunakan unsur manajemen 5M yang terdiri dari Man, Money, Material, Machine, dan Method (Kholifah et al., 2020). Subjek dalam penelitian ini adalah perekam medis di Puskesmas Paseh yang berjumlah 3 orang. Sedangkan untuk metode pengumpulan data penulis menggunakan metode observasi, studi pustaka dan wawancara mendalam dengan memberikan pertanyaan-pertanyaan yang telah disediakan untuk disajikan kepada responden. Analisis data yang digunakan yaitu univariat.

\section{HASIL DAN PEMBAHASAN}

Faktor-Faktor Penyebab Kerusakan Fisik Rekam Medis Rawat Jalan di Puskesmas Paseh 


\section{A. Hasil Penelitian}

Selama satu bulan melakukan penelitian (observasi) di Puskesmas Paseh peneliti menemukan 100 rekam medis yang rusak. Jumlah kerusakan dokumen dapat dilihat di tabel 1 dibawah ini :

Tabel 1. Jumlah Kerusakan Rekam Medis Rawat Jalan

\begin{tabular}{ccc}
\hline No. & Tahun & Jumlah dokumen yang rusak \\
\hline 1. & 2019 & 8 \\
\hline 2. & 2020 & 82 \\
\hline 3. & 2021 & 10 \\
\hline & Total & 100 \\
\hline
\end{tabular}

Sumber : Sub Bagian Filing di Puskesmas Paseh, 2021

Berdasarkan tabel 1 di atas menjelaskan pada tahun 2019 - 2021 terdapat 100 rekam medis dengan map yang mudah robek karena belum diganti dengan map yang lebih tebal. Ruang filing di Puskesmas Paseh masih terdapat dokumen yang disimpan didalam kardus karena kepadatan rak penyimpanan dan kurang nya rak penyimpanan/roll o'pack dikarenakan keadaan/kapasitas ruangan yang sempit/tidak memadai untuk penambahan rak.

Dapat disimpulkan bahwa kerusakan rekam medis di Puskesmas Paseh disebabkan oleh beberapa faktor berdasarkan unsur 5M, yaitu :

1. Unsur Man :

a. Pengetahuan/Pelatihan Petugas : Tergolong cukup, namun jika disesuaikan dengan standar maka pe petugas masih belum sesuai standar yang telah ditetapkan, karena 1 dari 3 perekam medis yang berpendidikan akhir SMA.

b. Kedisiplinan Petugas : Sudah cukup jadi tidak ada masalah.

c. Kegiatan Pelatihan Petugas : Belum pernah diadakannya kegiatan pelatihan terkait pemeliharaan rekam medis.

2. Unsur Money : Tidak ada permasalahan karena untuk anggaran dana untuk rekam medis yang berupa map di Puskesmas Paseh sudah mencukupi.

3. Unsur Material : Terdapat beberapa rekam medis masih menggunakan map putih yang kualitas bahannya tipis, kurangnya rak penyimpanan serta kondisi ruangan yang tidak memadai (sempit).

4. Unsur Machine : Penataan dokumen yang terlalu padat dan jumlah rak yang sedikit serta belum semua rekam medis di retensi.

5. Unsur Method : Tidak tersedia SOP tentang perlindungan dan pemeliharaan rekam medis.

\section{B. Pembahasan}

1. Faktor-faktor penyebab kerusakan fisik rekam medis rawat jalan berdasarkan unsur Man di Puskesmas Paseh

Salah satu faktor penyebab rusaknya rekam medis yaitu faktor man yang merujuk kepada sumber daya manusia yang berperan secara langsung dalam kegiatan sistem penyimpanan rekam medis. Sumber daya manusia yang berpengaruh dalam kegiatan ini adalah perekam medis. Variabel yang digunakan berdasarkan unsur man yaitu terdiri dari pengetahuan/pelatihan petugas, kedisiplinan dalam kerja serta kegiatan pelatihan petugas.

a. Pengetahuan/Pelatihan Petugas

Pengetahuan/Pelatihan petugas terhadap pentingnya menjaga, memelihara, dan merawat rekam medis sangatlah penting dan berpengaruh maka 
dari itu tingkat pendidikan petugas dapat berpengaruh. Perekam medis yang baik harus memiliki kompetensi yang baik yaitu dengan lulusan perekam medis. Berdasarkan hasil wawancara kepada salah satu dari 3 perekam medis di Puskesmas Paseh diketahui bahwa 2 petugas merupakan lulusan D3 rekam medis dan 1 petugas merupakan lulusan Sekolah Menengah Atas (SMA). Hal tersebut bisa dilihat pada tabel dibawah ini :

Tabel 2. Pendidikan Rekam Medis di Puskesmas Paseh

\begin{tabular}{clc}
\hline No & Nama Perekam Medis & Pendidikan Perekam Medis \\
\hline 1 & Perekam Medis 1 & SMA \\
\hline 2 & Perekam Medis 2 & D-III Rekam Medis \\
\hline 3 & Perekam Medis 3 & D-III Rekam Medis \\
\hline Sumber : & Perekam Medis di Puskesmas Paseh &
\end{tabular}

Berdasarkan tabel diatas menjelaskan bahwa 1 dari 3 perekam medis yang berpendidikan akhir Sekolah Menengah Atas (SMA), yang artinya unit rekam medis di Puskesmas Paseh masih belum sesuai standar yang telah ditetapkan, dimana perekam medis harus memiliki kualifikasi pendidikan formal minimal D3 rekam medis (Permenkes, 2020).

b. Kedisiplinan Kerja

Kedisiplinan Kerja merupakan sikap petugas terhadap peraturanperaturan yang tercermin dalam bentuk perilaku dalam melakukan suatu pekerjaan. Kedisiplinan kerja dalam penelitian ini adalah kedisiplinan petugas terhadap melakukan kegiatan pengelolaan rekam medis. Kedisiplinan perekam medis di Puskesmas Paseh sudah terbilang cukup, karena petugas akan langsung melakukan pergantian map apabila terdapat map yang rusak (robek). Hal ini dapat dilihat berdasarkan hasil observasi berikut dibawah ini:

\section{Tabel 3. Kedisiplinan Kerja Perekam Medis di Puskesmas Paseh}

\begin{tabular}{|c|c|c|c|}
\hline No. & Kategori Kedisiplinan & $\begin{array}{l}\text { True False } \\
\text { (Ya) Tidak) }\end{array}$ & Keterangan \\
\hline 1. & $\begin{array}{l}\text { Petugas langsung memberikan } \\
\text { map terhadap berkas rekam } \\
\text { medis yang belum tersampul. }\end{array}$ & V & $\begin{array}{l}\text { Pemberian map atau sampul } \\
\text { dilakukan di awal } \\
\text { pendaftaran jika pasien baru. }\end{array}$ \\
\hline 2. & $\begin{array}{l}\text { Petugas langsung melakukan } \\
\text { pergantian map apabila } \\
\text { terdapat dokumen yang rusak. }\end{array}$ & V & $\begin{array}{l}\text { Pergantian map dilakukan } \\
\text { pada saat petugas } \\
\text { menemukan rekam medis } \\
\text { yang rusak. }\end{array}$ \\
\hline 3. & $\begin{array}{l}\text { Petugas langsung memasukan } \\
\text { rekam medis apabila dokumen } \\
\text { telah dikembalikan. }\end{array}$ & V & $\begin{array}{l}\text { Petugas memasukan rekam } \\
\text { medis secara langsung } \\
\text { apabila dokumen rekam } \\
\text { medis telah kembalikan. }\end{array}$ \\
\hline
\end{tabular}

Sumber : Hasil observasi kedisiplinan kerja perekam medis di Puskesmas Paseh

Berdasarkan tabel 3 di atas menjelaskan bahwa perekam medis secara langsung akan melakukan pergantian map apabila terdapat dokumen yang rusak. Hal ini dapat disimpulkan bahwa kedisiplinan kerja perekam medis dalam pemeliharaan rekam medis tergolong cukup. Kedisiplinan dalam kerja merupakan sikap ketaatan dan kesetiaan petugas terhadap peraturan tertulis maupun tidak tertulis dalam bentuk perilaku dan perbuatan pada instansi untuk mencapai suatu tujuan (Wati \& Nuraini, 2019).

c. Kegiatan Pelatihan Petugas

Faktor-Faktor Penyebab Kerusakan Fisik Rekam Medis Rawat Jalan di Puskesmas Paseh 
Kegiatan pelatihan petugas dalam penelitian ini adalah salah satu proses untuk mengembangkan kemampuan petugas terkait kegiatan dibagian filling, penyimpanan, pengembalian dan peminjaman rekam medis. Berdasarkan hasil wawancara kepada salah satu perekam medis terkait pelatihan menyatakan bahwa petugas tidak pernah mengikuti pelatihan terkait kegiatan filling. Hal ini sesuai dengan hasil wawancara terhadap 1 dari 3 perekam medis yang menyatakan sebagai berikut: "nggak, filing mah otomatis ilmu rekam medis dari kita sendiri,ilmu dari kampus, diterapkan disini gitu, kalau seminar pernah, kita ikut seminar kalau ada yang ngadain dimana gitu”.

Berdasarkan dari hasil wawancara dan observasi tersebut dapat disimpulkan bahwa di Puskesmas Paseh belum pernah diadakan pelatihan untuk rekam medis terkait pemeliharaan rekam medis. Pelatihan yang dilakukan di Puskesmas Paseh secara internal yaitu dari ilmu rekam medis yang didapat dari kampus yang kemudian diterapkan di instansi. Pelatihan rekam medis sangat penting bagi petugas untuk meningkatkan pengetahuan dan keterampilan dalam penyelenggaraan pelayanan rekam medis sesuai dengan undang-undang No.13 tahun 2003 tentang ketenagakerjaan, tahun 2003 pelatihan kerja diselenggarakan dan diarahkan untuk membekali, meningkatkan dan mengembangkan kompetensi guna meningkatkan kemampuan, produktivitas dan kesejahteraan (Kholifah et al., 2020).

2. Faktor-faktor penyebab kerusakan fisik rekam medis rawat jalan berdasarkan unsur Money di Puskesmas Paseh

Money merupakan salah satu unsur yang tidak dapat diabaikan. Money adalah alat tukar dan alat pengukur nilai. Besar kecilnya hasil kegiatan dapat diukur dari jumlah uang yang beredar dalam perusahaan. Oleh karena itu uang merupakan alat yang penting untuk mencapai suatu tujuan karena segala sesuatu harus diperhitungkan secara rasional. Anggaran merupakan faktor penting bagi puskesmas, tanpa anggaran tentunya puskesmas tidak dapat menjalankan pelayanan dan melaksanakan operasionalisasi secara menyeluruh. Sasaran anggaran dapat dicapai melalui pelaksanaan serangkaian aktifitas yang telah ditetapkan sebelumnya dalam bentuk anggaran. Berikut hasil wawancara dari petugas, yaitu : "Anggaran dana ada, pasti ada dari bendahara".

Berdasarkan hasil dari wawancara tersebut maka dapat disimpulkan bahwa faktor money bisa menjadi penyebab kerusakan rekam medis, karena anggaran yang diberikan oleh pihak yang bersangkutan adalah berupa penyediaan map rekam medis. Bagian unsur money diketahui ada dana untuk pengelolaan rekam medis (Kamilia et al., 2020). Dana yang ada untuk kerusakan fisik rekam medis di Puskesmas Paseh sudah terpenuhi sehingga tidak ada kekurangan.

3. Faktor-faktor penyebab kerusakan fisik rekam medis rawat jalan berdasarkan unsur Material di Puskesmas Paseh

Material terdiri dari bahan setengah jadi (raw material) dan bahan jadi. Dalam dunia usaha untuk mencapai hasil yang lebih baik, selain manusia yang ahli dalam bidangnya juga harus dapat menggunakan bahan atau materi sebagai salah satu sarana. Sebab materi manusia tidak dapat dipisahkan, tanpa materi tidak akan tercapai hasil yang diinginkan. Map rekam medis di Puskesmas Paseh sudah cukup terlindungi. Hal ini didukung dengan hasil wawancara berikut : "cover yang beda yang warna putih ini bahannya agak tipis jadi mudah rusak beda dengan yang terbaru yang warna hijau, yang terbaru lumayan cukup tebal bahannya jadi ga mudah rusak".

Berikut adalah map rekam medis terbaru 2021 di Puskesmas Paseh : 

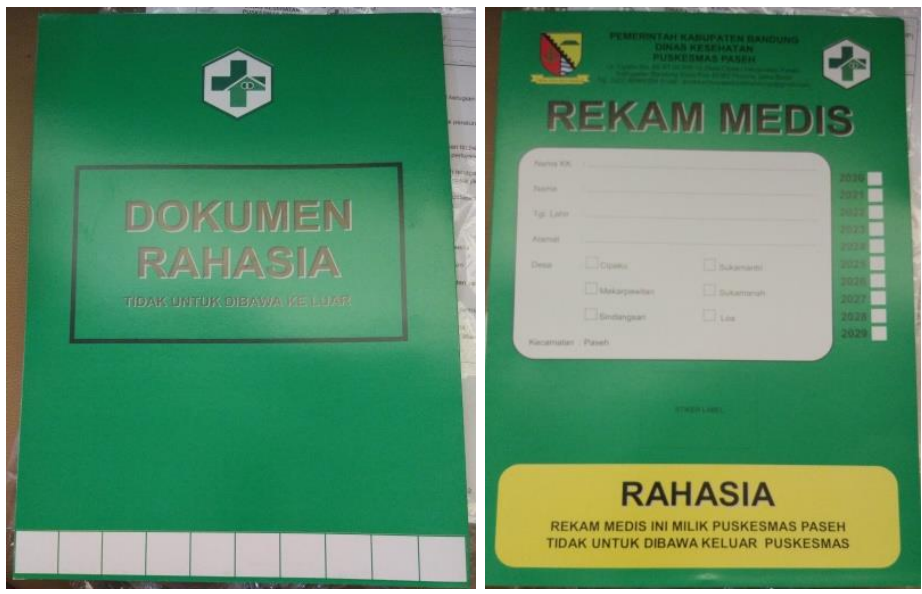

Gambar 1 : Map rekam medis baru

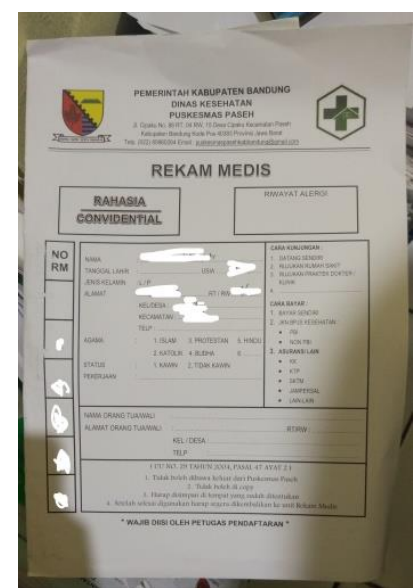

Gambar 2 : Map rekam medis lama

Berdasarkan dari gambar-gambar diatas yaitu rekam medis dengan map putih dan map hijau. Map yang berwarna putih merupakan map rekam medis lama sedangkan map yang berwarna hijau merupakan map rekam medis rawat jalan terbaru di Puskesmas Paseh. Map hijau tersebut baru dipakai pada tahun 2021, karena itu masih ada dokumen yang memakai map yang berwarna putih yang berbahan tipis yang mengakibatkan rekam medis mudah rusak/robek.

Dapat disimpulkan dari kedua gambar tersebut bahwa map hijau sudah cukup tebal akan tetapi kapasitas penyimpanan masih terlalu sempit/sedikit sehingga perlu penambahan rak penyimpanan. Dampak dari kerusakan dokumen yaitu pada keamanan, keteraturan dokumen, dan kerapian dalam menyimpan rekam medis di ruang penyimpanan. Penyebab ketidakrapian berkas yaitu kurangnya rak penyimpanan rekam medis pasien (Sahfitri, 2017).

\section{Faktor-faktor penyebab kerusakan fisik rekam medis rawat jalan} berdasarkan unsur Machine di Puskesmas Paseh

Machine atau mesin yang digunakan untuk memberi kemudahan atau menghasilkan keuntungan yang lebih besar serta menciptakan efisiensi kerja. Bagian filing merupakan salah satu bagian unit rekam medis yang berfungsi untuk menyimpan rekam medis, penyediaan rekam medis untuk berbagai keperluan, perlindungan arsip-arsip rekam medis terhadap kerahasiaan isi data dokumen, perlindungan dokumen terhadap kerusakan fisik, kimiawi, dan biologi (Kholifah 
et al., 2020). Dalam unsur machine ini alat yang digunakan untuk perlindungan dokumen juga mempermudah petugas dalam pengambilan dan pengembalian dokumen yaitu rak penyimpanan.

Berdasarkan hasil praktek kerja lapangan/observasi di Puskesmas Paseh bahwa kepadatan serta kekurangan rak penyimpanan dokumen dapat menyebabkan kerusakan pada rekam medis, karena kepadatan rak pada saat pengambilan dan pengembalian dokumen akan ditarik dan dimasukan dengan paksa sehingga rekam medis saling berdempetan dan terlipat di bagian ujung map, jika terus seperti itu maka lama kelamaan akan menyebabkan kerusakan pada dokumen. Jenis rak penyimpanan di Puskesmas Paseh yaitu menggunakan rak lemari yang terbuat dari kayu dan menggunakan rol o'pack.

Lemari atau rak penyimpanan yang terlalu rapat/padat juga dapat merusak kertas seperti kertas akan robek dan lusuh karena harus ditarik dengan paksa untuk keluar masuk (Palaguna \& Indrahti, 2016). Sementara di Puskesmas Paseh belum semua dokumen di retensi. Berikut dapat dibuktikan pada gambar dibawah ini :
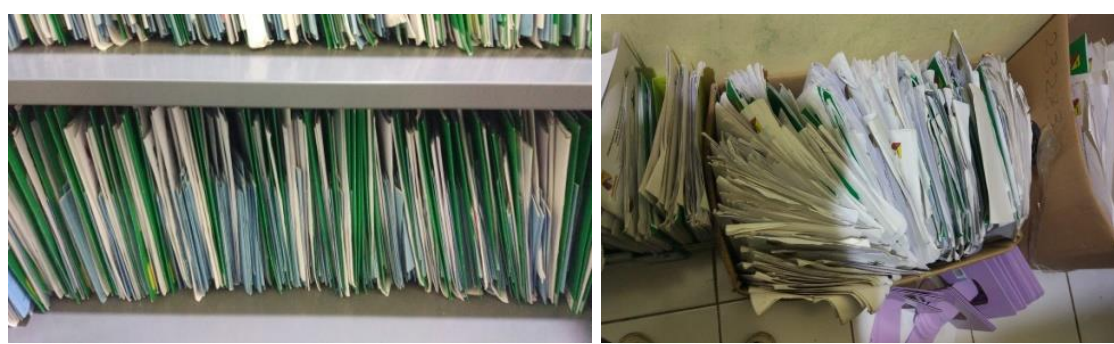

Gambar 4 : Kepadatan dokumen

Berdasarkan gambar diatas membuktikan bahwa terdapat rekam medis yang robek dikarenakan penataan dokumen yang terlalu padat dan jumlah rak yang sedikit serta belum semua rekam medis di retensi. Penyusutan atau retensi merupakan salah satu sarana penting untuk mengatasi masalah penumpukan rekam medis yang tidak lagi memiliki nilai guna. Berkas tersebut sebaiknya dimusnahkan agar tersedia tempat penyimpanan dan fasilitas pemeliharaan yang lebih baik terhadap rekam medis yang masih memiliki nilai guna (Cahyarida, n.d.).

\section{Faktor-faktor penyebab kerusakan fisik rekam medis rawat jalan} berdasarkan unsur Method di Puskesmas Paseh

Method atau metode yaitu suatu tata cara kerja yang baik, memfasilitasi, dan akan memperlancar jalannya suatu pekerjaan. Sebuah metode yang dinyatakan sebagai penetapan cara pelaksanaan suatu tugas dengan memberikan sebagai pertimbangan-pertimbangan untuk sarana, fasilitas-fasilitas yang tersedia dan penggunaan waktu, serta uang dan kegiatan usaha. Meskipun metode yang baik yaitu orang yang melaksanakannya tidak mengerti atau tidak memiliki pengalaman maka hasilnya tidak akan memuaskan. Peranan utama dalam manajemen tetap manusianya sendiri (Kholifah et al., 2020).

Standar Prosedur Operasional (SPO) adalah pedoman atau acuan untuk melaksanakan tugas dan pekerjaan sesuai dengan fungsi dari pekerjaan tersebut, dengan adanya SPO semua kegiatan di suatu instansi dapat terancang dengan baik dan berjalan sesuai kemauan instansi. SPO dapat didefinisikan sebagai berkas yang menjabarkan aktivitas operasional yang dilakukan sehari-hari dengan tujuan agar pekerjaan tersebut dilakukan dengan benar, tepat, dan konsisten untuk menghasilkan produk agar sesuai dengan standar yang telah ditetapkan sebelumnya (Gabriele, 2018). 
Puskesmas Paseh sudah memiliki beberapa SOP yang berlaku, misalnya SOP tentang perlindungan dan pemeliharaan rekam medis dari kerusakan dan pengrusakan. Hal ini dapat didukung dengan hasil wawancara berikut :

"nggak ada, paling SOP rekam medis, SOP kelengkapan rekam medis, $S O P$ kerahasiaan informasi rekam medis, pendaftaran, kelengkapan dan ketepatan isi rekam medis, sama pengisian udah segitu aja, kalau SOP tentang perlindungan dan pemeliharaan dokumen nggak ada".

Berdasarkan dari hasil wawancara tersebut dapat disimpulkan bahwa SPO tentang perlindungan dan pemeliharaan rekam medis di Puskesmas Paseh tidak ada, maka dari itu Puskesmas Paseh dianjurkan untuk membuat SPO terkait perlindungan dan pemeliharaan rekam medis serta melakukan sosialisasi. Sosialisasi adalah salah satu kebijakan strategi yang dilakukan untuk meningkatkan pemahaman dan kejelasan terhadap SPO yang akan dilaksanakan (Kusdamayanti et al., 2020).

Berdasarkan penelitian sebelumnya kondisi ruangan dalam keadaan berantakan dikarenakan belum dilaksanakannya retensi, akan tetapi pada penelitian saat ini kondisi ruangan dalam keadaan sudah rapi dikarenan sedang dilaksanakannya retensi, dan penataan dokumen yang terlalu padat sekarang sudah mulai renggang, sebagian dokumen yang belum dilakukan pembaruan cover saat ini sudah banyak dokumen yang dilakukan pembaruan. Namun untuk SOP sampai saat ini masih belum ada begitu juga dengan rak penyimpan dan ruangan belum bertambah.

\section{KESIMPULAN}

Berdasarkan hasil dari penelitian (observasi), studi pustaka dan wawancara di atas dapat disimpulkan bahwa terdapat 100 rekam medis rusak atau sobek di Puskesmas Paseh yang disebabkan oleh beberapa faktor berdasarkan unsur 5M, di antaranya Unsur Man : Pengetahuan petugas : Tergolong cukup, namun jika disesuaikan dengan standar maka pengetahuan/pelatihan petugas masih belum sesuai standar yang telah ditetapkan, karena 1 dari 3 perekam medis yang berpendidikan akhir SMA. Kedisiplinan petugas : Sudah cukup jadi tidak ada masalah. Kegiatan pelatihan petugas : Belum pernah diadakannya kegiatan pelatihan terkait pemeliharaan rekam medis. Unsur Money : Tidak ada permasalahanan karena untuk anggaran dana untuk rekam medis yang berupa map di Puskesmas Paseh sudah mencukupi. Unsur Material : Terdapat beberapa rekam medis masih menggunakan map putih yang kualitas bahannya tipis, kurangnya rak penyimpanan serta kondisi ruangan yang tidak memadai (sempit). Unsur Machine : Penataan dokumen yang terlalu padat dan jumlah rak yang sedikit serta belum semua rekam medis di retensi. Unsur Method: Tidak tersedia SOP tentang perlindungan dan pemeliharaan rekam medis.

\section{BIBLIOGRAFI}

Arif, M. R. (2018). Pengelolaan Arsip Rekam Medis di Rumah Sakit Aminah Tangerang. Jakarta: Fakultas Adab \& Humaniora UIN Syarif Hidayatullah.

Ayuningrum, T. A., Alfiansyah, G., Sugeng, S., \& Farlinda, S. (2020). Tinjauan Pelaksanaan Pemeliharaan Dokumen Rekam Medis di Ruang Filling RSUP Dr. Sardjito. J-REMI: Jurnal Rekam Medik Dan Informasi Kesehatan, 2(1), 107-113.

Cahyarida, I. (n.d.). Pemeliharaan Dan Peyusutan Arsip Dinamis Inaktif Di Unit Pusat Arsip Kementerian Energi Dan Sumber Daya Mineral. Fakultas Adab \& Humaniora UIN Syarif Hidayatullah Jakarta.

Faktor-Faktor Penyebab Kerusakan Fisik Rekam Medis Rawat Jalan di Puskesmas Paseh 
Gabriele, G. (2018). Analisis Penerapan Standar Operasional Prosedur (Sop) Di Departemen Marketing Dan Hrd PT Cahaya Indo Persada Artikel Ilmiah Jurnal Agora. Agora, 6(1).

Garmelia, E., Lestari, S., \& Golo, Z. A. (2021). Tinjauan Efektivitas Kerja Penanggung Jawab Rekam Medis (PJRM) di Bangsal Perawatan Sesuai dengan Kompetensi Perekam Medis dan Informasi Kesehatan (PMIK). Jurnal Manajemen Informasi Kesehatan Indonesia (JMIKI), 9(1), 5.

Kamilia, N., Wijayanti, R. A., \& Nurmawati, I. (2020). Identifikasi Faktor Penyebab Penumpukan Berkas Rekam Medis Aktif di RS Husada Utama. J-REMI: Jurnal Rekam Medik Dan Informasi Kesehatan, 1(4), 476-483.

Kholifah, A. N., Nuraini, N., \& Wicaksono, A. P. (2020). Analisis Faktor Penyebab Kerusakan Berkas Rekam Medis di Rumah Sakit Universitas Airlangga. J-REMI: Jurnal Rekam Medik Dan Informasi Kesehatan, 1(3), 364-373.

Kusdamayanti, F. A., Widayanti, M. R., \& Djajanti, C. W. (2020). Gambaran Pelaksanaan Standar Operasional Prosedur Pencegahan Dekubitus Pada Pasien Rawat Inap (Study Deskriptif Di Ruang Rawat Inap Rumah Sakit X Surabaya). Jurnal Penelitian Kesehatan, 10(2), 49-55.

Palaguna, S. K., \& Indrahti, S. (2016). Preservasi Arsip Rekam Medis Di Rumah Sakit Umum Daerah Dr. Soeselo Kabupaten Tegal. Jurnal Ilmu Perpustakaan, 5(3), 341$\underline{350 .}$.

Permenkes, R. I. (2008). Permenkes Nomor 269/Menkes/Per/III/2008 Tentang Rekam Medis. Jakarta: Kemenkes RI.

Permenkes, R. I. (2020). Peraturan Menteri Kesehatan Republik Indonesia Nomor 3 Tahun 2020 Tentang Klasifikasi Rumah Sakit. Peraturan Menteri Kesehatan Republik Indonesia.

Purnamasari, S., Mangesti, Y. A., \& Novianto, W. T. (2017). Implementasi Kebijakan Penurunan Angka Kematian Ibu di Kabupaten Banyumas. Jurnal Hukum Dan Pembangunan Ekonomi, 6(1).

Sahfitri, Y. (2017). Tinjauan aspek keamanan berkas rekam medis di ruang penyimpanan rst dr. Soetarto yogyakarta.

Sandika, T. W. (2019). Tinjauan Pelaksanaan Pemeliharaan Dokumen Rekam Medis Di Ruang Filing Rumah Sakit Jiwa Prof. dr. muhammad Ildrem Medan Tahun 2018. Jurnal Ilmiah Perekam Dan Informasi Kesehatan Imelda (JIPIKI), 4(1), 560-566.

Sebayang, S. B. (2018). Faktor Penyebab Kerusakan Dokumen Rekam Medis di Ruang Penyimpanan RSU Mitra Sejati Medan. Jurnal Ilmiah Perekam Dan Informasi Kesehatan Imelda (JIPIKI), 3(1), 386-393.

Suryanto, H. (2020). Analisis Beban Kerja dan Kebutuhan Sumber Daya Manusia Petugas Rekam Medis Puskesmas Adan-adan Kabupaten Kediri Analysis of Workload and Human Resources Needs at the Adan-adan Health Center in Kediri District. Jurnal Rekam Medis Dan Informasi Kesehatan, 3(1).

Wati, T. G., \& Nuraini, N. (2019). Analisis Kejadian Missfile Berkas Rekam Medis Rawat Jalan di Puskesmas Bangsalsari. Rekam Medik Dan Informasi Kesehatan.

Yuliani, N. (2016). Faktor-Faktor Yang Mempengaruhi Keamanan Berkas Rekam Medis Berdasarkan Peraturan Perundang-Undangan (Studi Kasus Di Rumah Sakit Umum Daerah Sukoharjo). Jurnal INFOKES Universitas Duta Bangsa Surakarta, 6(1).

(C) 2021 by the authors. Submitted for possible open access publication under the terms and conditions of the Creative Commons Attribution (CC BY SA) license (https://creativecommons.org/licenses/by-sa/4.0/). 